\title{
COLON-COLONIC INVAGINATION CAUSED BY CECUM CANCER - A CASE REPORT
}

\author{
Saša Dragović
}

\begin{abstract}
Invagination (intussusception) represents telescoping of the proximal segment of the intestine (intususceptum) into the distal segment of the intestine (intususcepiens). We report the case of a patient with colon-colonic invagination caused by adenocarcinoma of the cecum as one of the rare causes of colonic invagination.

Multidetector computerized tomography of the abdomen and lesser pelvis is a diagnostic method of choice and intestine resection according to the principle of oncological resection is a treatment of choice in adults with malignant etiology of the disease.
\end{abstract}

Acta Medica Medianae 2019;58(3):93-96.

Key words: invagination (intussusception), multidetector computerized tomography, colon, surgical treatment, resection

General Surgery Clinic of the Military Medical Academy,

Belgrade, Serbia

Contact: Saša Dragović

Crnotravska 17, 11000 Belgrade, Serbia

E-mail: s.dragovic22@gmail.com

\section{Introduction}

Invagination (intussusception) was first mentioned in 1674 by Barbette of Amsterdam (1) and later, in 1789, it presented in more detail in a report by John Hunter as intussusception - telescoping of the proximal segment of the intestine (intususceptum) into the distal segment of the intestine (intususcepiens) (2). The first invagination operation was performed by Ser Jonathan Hutchinson in 1871 (3). The highest percentage of invagination is present in infants and children, whereas it is present in as much as $5 \%$ of adults (4).

Contrary to the younger population where the cause of intussusception is unknown, the most frequent cause in adults are malignant processes in the intestines, primarily in the colon.

The clinical picture of intussusception in infants and children is dominated by a sudden onset of the disease followed by cramps, vomiting and bloody mucus in stool, while in adults it is followed by subacute and chronic nonspecific problems (constipation, diarrhea, etc.) (5-7).

\section{Case Presentation}

The patient M. V., aged 82 , was admitted with pain located paraumbilically to the right. The pain had lasted for three days and the patient had nausea without the urge to vomit. During the last three days, the stool had liquid consistency without blood and mucus. The patient denied febrility and dysuric problems. She was treated for hypothyreosis (she was taking Letrox) and denied other chronic significant diseases. She had pollen allergy and denied allergies to medications. Family history was not significant.

On admission, the patient was conscious, oriented in space, time and person, communicative. The skin and visible mucosa had normal color and hemodynamic compensation. She was afebrile, eupneic, normotensive, the tongue was moist and uncoated. The head, neck and thorax had no specific findings. The abdomen was in line with the thorax, soft on palpation, painful on deep palpation paraumbilically to the right where a $5 \times 5 \mathrm{~cm}$ movable tumefaction could be palpated. Abdominal musculature was without defense and without peritoneal irritation on palpation. On auscultation, gurgling sound was heard above the abdomen. No abdominal herniation was present. The extremities were not swollen or deformed.

Laboratory findings were normal.

Multidetector computerized tomography (MD$\mathrm{CT}$ ) of the abdomen and lesser pelvis showed intussusception of the cecum with ileocecal valve into the 
ascending colon. Cecal fundus was located in the ascending colon towards the hepatic flexure. Mesenteric pedicle of the ileocecal segment protruding into colon lumen is observed. Signs of subocclusion were observed in the small intestine.

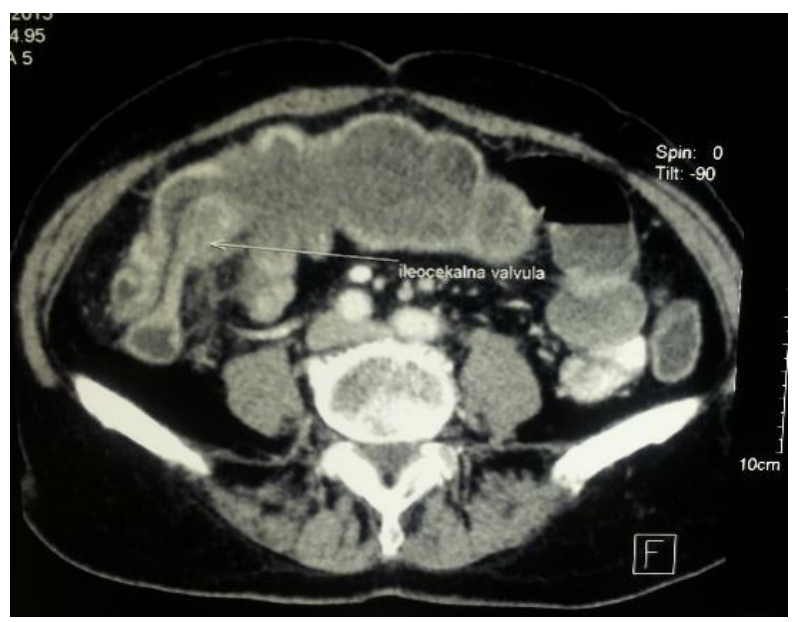

Figure 1

After the diagnosis, the following surgical intervention was indicated and performed: laparotomia explorativa. Hemicolectomia dex. cum ileotransversocolo anastomosis termino-lateralis.

Intraoperative findings: No free fluid present in the abdomen. Parietal and visceral peritoneum showed no changes in the form of secondary deposits. Adhesions were present between the omentum and anterior abdominal wall. Intussusception of the cecum with ileocecal valve in the ascending colon was found. Cecotomy was performed. A $5 \times 5 \mathrm{~cm}$ infiltrate of hard consistency was found which involved all layers of the wall, did not perforate the serous membrane and partially occluded the lumen of the intestines. Figures 2 and 3.

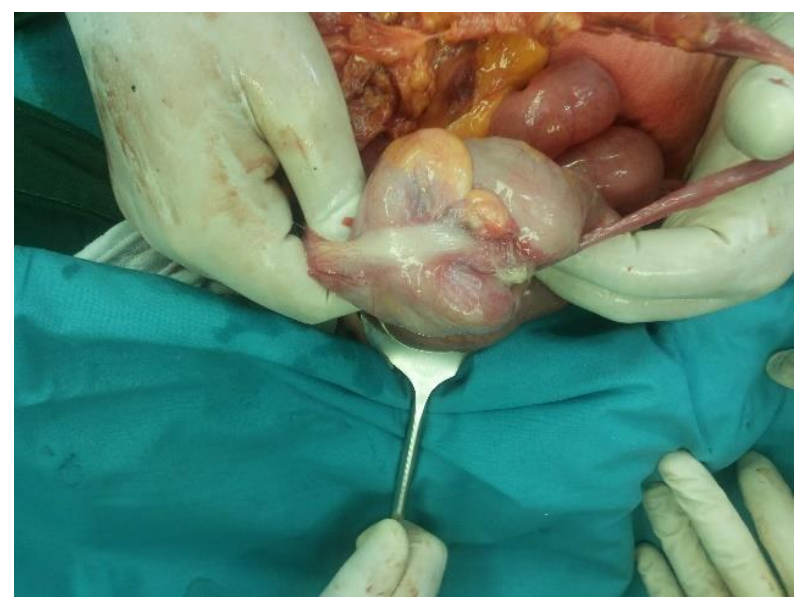

Figure 2. Invagination caused by tumor

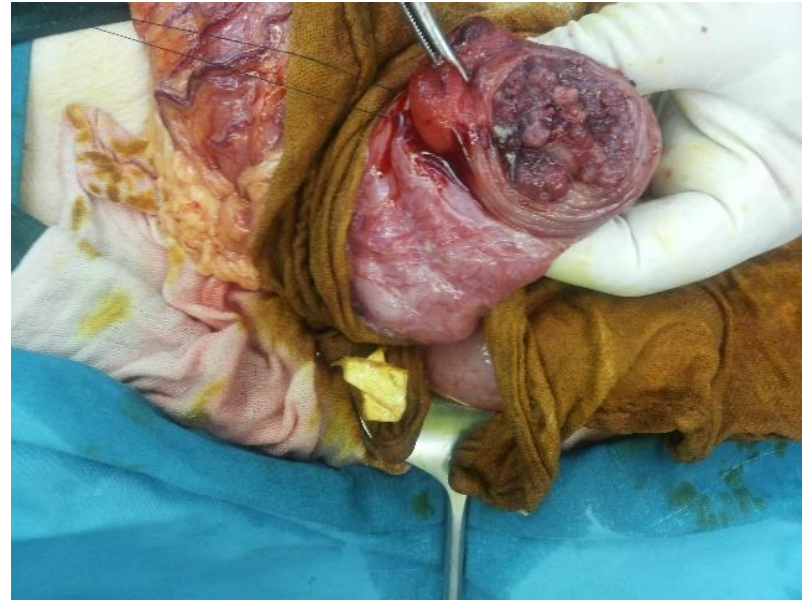

Figure 3. Invagination caused by tumor

Pathohistological examination of the preparation: macroscopically - the resection was the final part of the small intestine, $190 \mathrm{~mm}$ long, the cecum without appendix, the ascending and part of transversal colon $250 \mathrm{~mm}$ long, with associated fat tissue. The cecum was completely filled with lobulated tumor mass, pink and with softer consistency. Microscopically - polypoidmucinous adenocarcinoma, well -differentiated, spreading infiltratively, without venous and lymphatic invasion, with absent metastases in lymphatic nodes (0/24) and with no tumor on the edges of the resection. Final histopathological findings: Adenocarcinoma mucinosuminvasivum intestine crassi HG1 in stadio B secundum Dukes ((B3 secundum Astler Coller) pT4b NO(0/24) Mx secundum AJCC/UICC TNM LOVO.

Postoperative course was regular. Bowel transit was established. Nasogastric probe was taken out on the third day. The drain was removed on the fifth day. Sutures were removed on the tenth postoperative day. Medical advisory board for malignant diseases of the digestive tract: regular checkups and monitoring were indicated.

The first control checkup with a surgeon one month later: findings were regular.

\section{Discussion}

Invagination (intussusception) in adults is clinically manifested by nonspecific, chronic problems which point to a possible bowel obstruction. The most common symptom is abdominal pain followed by vomiting and nausea. The exact mechanism of development is unknown but it is believed that a lesion in the intestinal wall or presence of an irritant in lumen initiates invagination by changing the normal intestinal peristalsis. The presence of palpable masses in the abdomen is present in $24 \%$ to $42 \%$ of examined patients. Invagination may be indicated by the presence of a movable mass in the abdomen along with the above mentioned symptoms $(4,5)$.

The dominant locations of intussusception are the places where movable segments of the colon go into the less movable segment (8). 
Invagination is classified into four groups according to the place of origin:

1) entero-enteric, limited to the small intestine,

2) colon-colonic, which includes only the segments of the colon,

3) ileo-colonic, prolapse of the terminal ileum into the colon and

4) ileo-cecal, the main initiator of invagination is ileocecal valve $(6,9,10)$.

The diagnosis is established based on history data, clinical picture and diagnostic procedures (native RTG graph of the abdomen, abdominal ultrasound, MDCT of the abdomen, colonoscopy).

Native RTG graph of the abdomen is usually the first diagnostic procedure which shows the signs of bowel obstruction and provides initial information about the location of the obstruction (11).

Ultrasound diagnostics as an easily available and noninvasive procedure has its application in the diagnosis of intussusception with signs of pseudokidney but it also has drawbacks due to the masking of the visual field by gas collections in the intestines (12).

Colonoscopy can visually determine the exact cause of the obstruction, do the biopsy of the change and its location and it is an appropriate method particularly in nonspecific, chronic problems (13).
In the last several years, MDCT scanner has become the leading diagnostic procedure which shows the exact location of intussusception and helps to plan surgical intervention (14).

Invagination in infants and children can be resolved with barium irigography or air insufflation into the colon. The treatment of invagination in adults is in most cases finalized surgically. Oncological principles of large intestine resection are performed due to malignant processes which are dominant in the etiology $(15,16)$.

Medial laparotomy has mostly been used so far as an approach in surgical treatment and recently, laparoscopic resection of the small and large intestine has been introduced into practice in recent years observing the oncologic principles of resection $(17,18)$.

\section{Conclusion}

Intestinal invagination in adults is rare and the main cause is a malignant process. MDCT scan of the abdomen is the most specific and the most sensitive preoperative diagnostic method. The treatment of invagination of intestines in adults is, as a rule, surgical. The principles of surgical treatment include oncological resection of the intestines by the use of classic or laparoscopic approach.

\section{References}

1. de Moulin D. Paul Barbette, M.D.: a seventeenthcentury Amsterdam author of best-selling textbooks. Bull Hist Med 1985;59(4):506-14. [CrossRef] [PubMed]

2. Noble I. Master surgeon: John Hunter. J. Messner: New York; 1971. p. 185.

3. Hutchinson $\mathrm{H}$, Hutchinson J. Jonathan Hutchinson: life and letters. 1st ed. Wm Heinemann Medical Books: London; 1946.

4. Azar T, Berger DL. Adult intussusception. Ann Surg 1997;226(2): 134-8. [CrossRef] [PubMed]

5. Begos DG, Sandor A, Modlin IM. The diagnosis and management of adult intussusception. Am J Surg 1997;173(2):88-94. [CrossRef] [PubMed]

6. Weilbaecher D, Bolin JA, Hearn D, Ogden W $2^{\text {nd }}$. Intussusception in adults. Review of 160 cases. Am J Surg 1971;121(5): 531-5. [CrossRef] [PubMed]

7. Felix EL, Cohen MH, Bernstein AD, Schwartz JH. Adult intussusception; case report of recurrent intussusception and review of the literature. Am J Surg 1976; 131(6): 758-61. [CrossRef] [PubMed]
8. Wang LT, Wu CC, Yu JC, Hsiao CW, Hsu CC, Jao SW. Clinical entity and treatment strategies for adult intussusceptions: 20 years' experience. Dis Colon Rectum 2007;50(11): 1941-9. [CrossRef] [PubMed]

9. Nagorney DM, Sarr MG, McIlrath DC. Surgical management of intussusception in the adult. Ann Surg 1981;193(2): 230-6. [CrossRef] [PubMed]

10. Amoruso M, D'Abbicco D, Praino S, Conversano A, Margari A. Idiopathic adult colo-colonic intussusception: case report and review of the literature. Int J Surg Case Rep 2013;4(4): 416-8. [CrossRef][PubMed]

11. Eisen LK, Cunningham JD, Aufses AH Jr. Intussusception in adults: institutional review. J Am Coll Surg 1999;188(4): 390-5. [CrossRef][PubMed]

12. Cerro $P$, Magrini L, Porcari $P$, De Angelis O. Sonographic diagnosis of intussusceptions in adults. Abdom Imaging 2000;25(1):45-7. [CrossRef][PubMed]

13. Hurwitz LM, Gertler SL. Colonoscopic diagnosis of ileocolic intussusception. Gastrointest Endosc1986; 32(3): 217-8. [CrossRef] [PubMed] 
14. Takeuchi K, Tsuzuki $Y$, Ando T, Sekihara M, Hara T, Kori $\mathrm{T}$, et al. The diagnosis and treatment of adult intussusception. J Clin Gastroenterol 2003;36:18-21. [CrossRef] [PubMed]

15. Reijnen HA, Joosten $\mathrm{HJ}$, de Boer HH. Diagnosis and treatment of adult intussusception. Am J Surg 1989; 158(1): 25-8. [CrossRef] [PubMed]

16. Wolff BC, Boller AM. Large bowel obstruction. In: JL Cameron, editor. Current surgical therapy. Mosby Elsevier: Philadelphia; 2008. pp. 189-192.
17. McKay R. Ileocecal intussusception in an adult: the laparoscopic approach. JSLS 2006;10(2): 250-3.

[CrossRef] [PubMed]

18. Jelenc F, Brencic E. Laparoscopically assisted resection of an ascending colon lipoma causing intermittent intussusception. J Laparoendosc Adv Surg Tech A. 2005;15(2): 173-5. [CrossRef] [PubMed]

\title{
KOLONO-KOLONIČNA INVAGINACIJA IZAZVANA KARCINOMOM CEKUMA - PRIKAZ SLUČAJA
}

\author{
Saša Dragović \\ Klinika za opštu hirurgiju Vojnomedicinske Akademije , Beograd, Srbija \\ Kontakt: Saša Dragović \\ Crnotravska 17, 11000 Beograd, Srbija \\ E-mail: s.dragovic22@gmail.com \\ Invaginacija (intususcepcija) predstavlja uvlačenje proksimalnog segmenta creva (intu- \\ susceptum) u distalni segment creva (intususcepiens). \\ Studija daje prikaz bolesnika sa kolono-koloničnom invaginacijom uzrokovanom adeno- \\ karcinomom cekuma, kao jednim od ređih uzroka kolonične invaginacije. \\ Multidetektorska kompjuterizovana tomografija trbuha i male karlice dijagnostika je \\ izbora, a resekcija creva, po principu onkološke resekcije terapija je izbora invaginacije u \\ odraslih osoba kod maligne etiologije bolesti.
}

Acta Medica Medianae 2019;58(3):93-96.

Ključne reči: invaginacija (intususcepcija), multidetektorska kompjuterizovana tomografija, kolon, hirurško lečenje, resekcija 